\title{
Perspectives of pharmacy students, pharmacy academics and practicing pharmacists on interprofessional education and collaborative practice: a comprehensive systematic review protocol
}

\author{
Alla El-Awaisi ${ }^{1,2}$ \\ Lesley Diack $^{2}$ \\ Sundari Joseph ${ }^{3}$ \\ Maguy El Hajj ${ }^{1}$
}

1. College of Pharmacy, Qatar University, Doha, Qatar

2. School of Pharmacy and Life Sciences, Faculty of Health and Social Care, The Robert Gordon University, Aberdeen, Scotland, United Kingdom

3. School of Nursing and Midwifery, Faculty of Health and Social Care, Robert Gordon University, Aberdeen, Scotland, United Kingdom

\section{Corresponding author: \\ Alla El-Awaisi \\ elawaisi@qu.edu.qa}

\section{Review question/objective}

The objective of this systematic review is to examine the perspectives, attitudes, views and experiences of pharmacy students, pharmacy academics and practicing pharmacists towards interprofessional education and collaborative practice through quantitative and qualitative evidence.

\section{Background}

Interprofessional education (IPE) has been defined by the Centre for the Advancement of Interprofessional Education (CAIPE) as "two or more professions learn with, from and about each other to improve collaboration and the quality of care". ${ }^{1 \text { (para1) }}$ Globally, interprofessional education has gained momentum in the last twenty years. However, this has been more pronounced in developed countries such as Canada, United States, Australia and the United Kingdom. In an IPE environment, students are provided with a structured opportunity that enables them to interact with other healthcare professionals where they acquire the knowledge, skills and professional attitudes as part of their undergraduate learning experience. ${ }^{2}$ Once they graduate, they are able to translate this into practice. The practice environment is often complex and intense, and requires a high level of interpersonal skills for the health care professional to be able to work in an adaptable, flexible and collaborative environment and to appreciate the roles of the different health care professionals. ${ }^{2}$ Health professionals learning together and understanding each other better is the way forward and has been proven by international research evidence..$^{3,4,5,6}$ 
As healthcare systems advance, the demand for collaborative work between healthcare professionals from different backgrounds increases; therefore, healthcare professionals need to develop the knowledge and skills required to work together effectively in order to positively impact on patient care. As a result, the World Health Organization (WHO) published a ground-breaking document titled, "Framework for Action on Interprofessional Education and Collaborative Practice" in 2010. ${ }^{6}$. In this framework, WHO strongly advocated the development and integration of IPE into healthcare curricula. They emphasized the importance of adapting team based collaborative models in all the different areas of healthcare to enhance the delivery of healthcare services. Collaborative practice occurs "when multiple health workers from different professional backgrounds work together with patients, families, carers, and communities to deliver the highest quality of care". ${ }^{\left({ }^{(13)}\right)}$ Therefore, collaboration involves solving challenging problems together, interacting, negotiating and jointly working with health workers from any background. This is where two or more healthcare professionals work cohesively to address patient needs. Benefits of collaborative practice include strengthening health care systems and improving patient care in terms of quality and safety provided, reducing the cost of care, shortening patients' duration of hospital stay, and improving health outcomes. ${ }^{6,7}$

In terms of pharmacy and the expanding and evolving role of the pharmacist seen in the early nineties with the emergence of the concept of pharmaceutical care concept by Hepler and Strand, ${ }^{8}$ it is important that this role is recognized and understood by other healthcare providers and healthcare students so that there is effective collaboration and team work. With this in mind, pharmacists also need to recognize and understand other professionals' roles. Pharmacists need to be able to assume new innovative roles centered on patient care rather than being product centered. These roles include medication reviews, chronic disease management, immunization services, well-being programs, prescribing and becoming an integral part healthcare decision making team based on evidence based practice.

A number of systematic reviews on IPE exist with the first one dating back to 1999. These found no rigorous quantitative evidence on the effects of IPE. ${ }^{9}$ Table 1 summarizes the main systematic reviews to date focusing on IPE. 
Table 1: Existing systematic reviews on IPE

\begin{tabular}{|c|c|c|c|c|c|c|}
\hline Date & Authors & Title & Objectives & Databases used & Number of articles & Authors' conclusion \\
\hline 1999 & $\begin{array}{l}\text { Zwarenstein M, } \\
\text { Atkins J, Barr H, } \\
\text { Hammick M, } \\
\text { Koppel I, and } \\
\text { Reeves S. }\end{array}$ & $\begin{array}{l}\text { A systematic } \\
\text { review of } \\
\text { interprofessional } \\
\text { education }\end{array}$ & $\begin{array}{l}\text { To assess the } \\
\text { effects of IPE } \\
\text { interventions on } \\
\text { collaborative } \\
\text { working between } \\
\text { different } \\
\text { professionals, and } \\
\text { on the quality and } \\
\text { outcomes of care } \\
\text { provided to } \\
\text { patients/clients. }\end{array}$ & $\begin{array}{l}\text { Medline (from 1966) and } \\
\text { CINAHL (from 1082). }\end{array}$ & $\begin{array}{l}\text { The search strategy } \\
\text { identified } 510 \text { from } \\
\text { Medline and } 552 \text { articles } \\
\text { from CINAHL. Of these, } 39 \\
\text { articles from Medline and } \\
44 \text { from CINAHL were } \\
\text { selected. }\end{array}$ & $\begin{array}{l}\text { No rigorous } \\
\text { quantitative evidence } \\
\text { exists on the effects of } \\
\text { interprofessional } \\
\text { education. } \\
\text { No published evidence } \\
\text { that IPE promotes } \\
\text { interprofessional } \\
\text { collaboration or } \\
\text { improves client } \\
\text { relevant outcomes. }\end{array}$ \\
\hline
\end{tabular}




\begin{tabular}{|c|c|c|c|c|c|c|}
\hline Date & Authors & Title & Objectives & Databases used & Number of articles & Authors' conclusion \\
\hline 2001 & $\begin{array}{l}\text { Zwarenstein M, } \\
\text { Reeves S, Barr } \\
\mathrm{H}, \text { Hammick M, } \\
\text { Koppel I, and } \\
\text { Atkins J. }{ }^{10}\end{array}$ & $\begin{array}{l}\text { Interprofessional } \\
\text { education: effects } \\
\text { on profession } \\
\text { practice and } \\
\text { health care } \\
\text { outcomes }\end{array}$ & $\begin{array}{l}\text { To assess the } \\
\text { usefulness of IPE } \\
\text { interventions } \\
\text { compared to } \\
\text { education in which } \\
\text { the same } \\
\text { professions were } \\
\text { learning separately } \\
\text { from one another. }\end{array}$ & $\begin{array}{l}\text { Cochrane register, } \\
\text { MEDLINE (1968 - 1998) } \\
\text { and CINAHL (1982 - } \\
\text { 1998). Journal of } \\
\text { Interprofessional Care } \\
\text { was hand searched } \\
\text { (1992 - 1998), the } \\
\text { Centre for the } \\
\text { Advancement of } \\
\text { Interprofessional } \\
\text { Education Bulletin (1987 } \\
\text { - 1998), conference } \\
\text { proceedings, the 'grey } \\
\text { literature' held by } \\
\text { relevant organizations, } \\
\text { and reference lists of } \\
\text { articles. }\end{array}$ & $\begin{array}{l}\text { The search strategy } \\
\text { initially identified } 1042 \\
\text { articles, of which } 89 \text { were } \\
\text { selected. However, none } \\
\text { of these studies met the } \\
\text { inclusion criteria. }\end{array}$ & $\begin{array}{l}\text { Studies lacked the } \\
\text { methodological rigor } \\
\text { needed to understand } \\
\text { the impact of IPE on } \\
\text { professional practice } \\
\text { and/or health care } \\
\text { outcomes. }\end{array}$ \\
\hline
\end{tabular}




\begin{tabular}{|c|c|c|c|c|c|c|}
\hline Date & Authors & Title & Objectives & Databases used & Number of articles & Authors' conclusion \\
\hline 2001 & $\begin{array}{l}\text { Cooper, } \mathrm{H}, \\
\text { Carlisle, } \mathrm{C} \text {, } \\
\text { Gibbs, } \mathrm{T} \text {, and } \\
\text { Watkins, } \mathrm{C}^{11}\end{array}$ & $\begin{array}{l}\text { Developing an } \\
\text { evidence base for } \\
\text { interdisciplinary } \\
\text { learning: a } \\
\text { systematic review }\end{array}$ & $\begin{array}{l}\text { To explore the } \\
\text { feasibility of } \\
\text { introducing } \\
\text { interdisciplinary } \\
\text { education within } \\
\text { undergraduate } \\
\text { health professional } \\
\text { programs. }\end{array}$ & $\begin{array}{l}\text { Various online } \\
\text { databases. } \\
\text { Dates not mentioned. }\end{array}$ & $\begin{array}{l}\text { The search strategy } \\
\text { identified } \\
141 \text { articles but only } 30 \\
\text { were included in the } \\
\text { analysis because of lack of } \\
\text { methodological rigor in the } \\
\text { research and poorly } \\
\text { developed outcome } \\
\text { measures. }\end{array}$ & $\begin{array}{l}\text { Student health } \\
\text { professionals were } \\
\text { found to benefit from } \\
\text { interdisciplinary } \\
\text { education with } \\
\text { outcome effects } \\
\text { primarily relating to } \\
\text { changes in knowledge, } \\
\text { skills, attitudes and } \\
\text { beliefs. Effects upon } \\
\text { professional practice } \\
\text { were not discernible } \\
\text { and educational and } \\
\text { psychological theories } \\
\text { were rarely used to } \\
\text { guide the development } \\
\text { of the educational } \\
\text { interventions. }\end{array}$ \\
\hline
\end{tabular}




\begin{tabular}{|c|c|c|c|c|c|c|}
\hline Date & Authors & Title & Objectives & Databases used & Number of articles & Authors' conclusion \\
\hline 2006 & $\begin{array}{l}\text { Clifton M, Dale } \\
\text { C, and } \\
\text { Bradshaw C. }{ }^{12}\end{array}$ & $\begin{array}{l}\text { The impact and } \\
\text { effectiveness of } \\
\text { inter-professional } \\
\text { education in } \\
\text { primary care: an } \\
\text { RCN literature } \\
\text { review }\end{array}$ & $\begin{array}{l}\text { To describe the } \\
\text { range and extent of } \\
\text { IPE in primary care. } \\
\text { To identify literature } \\
\text { that reports on the } \\
\text { impact and } \\
\text { effectiveness of IPE } \\
\text { in primary care. } \\
\text { To evaluate the } \\
\text { literature in terms of } \\
\text { methodologies. } \\
\text { To analyze the } \\
\text { literature to identify } \\
\text { common themes. } \\
\text { To identify the best } \\
\text { practice in primary } \\
\text { care IPE. } \\
\text { To identify gaps in } \\
\text { the evidence } \\
\text { Make } \\
\text { recommendations } \\
\text { about future } \\
\text { developments in } \\
\text { primary care IPE. }\end{array}$ & $\begin{array}{l}\text { The review focused on } \\
\text { Medline, CIHNAL and } \\
\text { Social Care Online for } \\
\text { the period } 2000-2006\end{array}$ & $\begin{array}{l}\text { The search strategy } \\
\text { identified } 583 \text { research } \\
\text { articles, } 67 \text { were } \\
\text { considered and } 20 \text { were } \\
\text { included. }\end{array}$ & $\begin{array}{l}\text { No high quality } \\
\text { evidence on the } \\
\text { effectiveness of IPE in } \\
\text { primary care. }\end{array}$ \\
\hline
\end{tabular}




\begin{tabular}{|c|c|c|c|c|c|c|}
\hline Date & Authors & Title & Objectives & Databases used & Number of articles & Authors' conclusion \\
\hline 2007 & $\begin{array}{l}\text { Hammick M, } \\
\text { Freeth D, Koppel } \\
\text { I, Reeves S, and } \\
\text { Barr H. }^{3}\end{array}$ & $\begin{array}{l}\text { A best evidence } \\
\text { systematic review } \\
\text { of } \\
\text { interprofessional } \\
\text { education: BEME } \\
\text { Guide no. } 9\end{array}$ & $\begin{array}{l}\text { To identify and } \\
\text { review the strongest } \\
\text { evaluations of IPE. } \\
\text { To classify the } \\
\text { outcomes of IPE and } \\
\text { note the influence of } \\
\text { context on particular } \\
\text { outcomes. } \\
\text { To identify and } \\
\text { discuss the } \\
\text { mechanisms that } \\
\text { underpin and inform } \\
\text { positive and } \\
\text { negative outcomes } \\
\text { of IPE. }\end{array}$ & $\begin{array}{l}\text { Medline 1966-2003, } \\
\text { CINAHL 1982-2001, } \\
\text { BEI 1964-2001, ASSIA } \\
\text { 1990-2003 }\end{array}$ & $\begin{array}{l}\text { The search strategy } \\
\text { identified 10,495 } \\
\text { abstracts. } 884 \text { full articles } \\
\text { were selected. } 21 \text { article } \\
\text { were included. }\end{array}$ & $\begin{array}{l}\text { Importance for } \\
\text { government to call for } \\
\text { enhanced } \\
\text { collaboration. } \\
\text { Staff development is } \\
\text { crucial. } \\
\text { Authenticity and } \\
\text { customization of IPE } \\
\text { are important } \\
\text { mechanisms for } \\
\text { positive outcomes of } \\
\text { IPE. } \\
\text { IPE is well received, } \\
\text { enabling knowledge } \\
\text { and skills necessary for } \\
\text { collaborative work. }\end{array}$ \\
\hline
\end{tabular}




\begin{tabular}{|c|c|c|c|c|c|c|}
\hline Date & Authors & Title & Objectives & Databases used & Number of articles & Authors' conclusion \\
\hline 2008 & $\begin{array}{l}\text { Reeves S, } \\
\text { Zwarenstein M, } \\
\text { Goldman J, Barr } \\
\text { H, Freeth D, } \\
\text { Hammick M, and } \\
\text { Koppel I. }{ }^{5}\end{array}$ & $\begin{array}{l}\text { Interprofessional } \\
\text { education: effects } \\
\text { on professional } \\
\text { practice and } \\
\text { health care } \\
\text { outcomes }\end{array}$ & $\begin{array}{l}\text { To assess the } \\
\text { effectiveness of IPE } \\
\text { interventions as } \\
\text { compared to } \\
\text { education } \\
\text { interventions in } \\
\text { which the same } \\
\text { health and social } \\
\text { care professionals } \\
\text { learn separately } \\
\text { from one another. } \\
\text { To assess the } \\
\text { effectiveness of IPE } \\
\text { interventions as } \\
\text { compared to no } \\
\text { education } \\
\text { intervention. }\end{array}$ & $\begin{array}{l}\text { Cochrane register, } \\
\text { MEDLINE and CINAHL } \\
\text { (1999-2006). } \\
\text { Hand searched the } \\
\text { journal of } \\
\text { interprofessional care } \\
\text { (1999-2006), relevant } \\
\text { conferences, textbooks } \\
\text { and IPE organizations } \\
\text { websites. }\end{array}$ & $\begin{array}{l}\text { The search strategy } \\
\text { retrieved } 1801 \text { abstracts, } \\
56 \text { identified, and then six } \\
\text { studies (four randomized } \\
\text { controlled trials and two } \\
\text { controlled before and after } \\
\text { studies) were included. }\end{array}$ & $\begin{array}{l}\text { It is not possible to } \\
\text { draw generalizable } \\
\text { inferences about the } \\
\text { key elements of IPE } \\
\text { and its effectiveness. } \\
\text { More rigorous IPE } \\
\text { studies are needed to } \\
\text { provide better } \\
\text { evidence of the impact } \\
\text { of IPE on professional } \\
\text { practice and } \\
\text { healthcare outcomes. }\end{array}$ \\
\hline
\end{tabular}




\begin{tabular}{|c|c|c|c|c|c|c|}
\hline Date & Authors & Title & Objectives & Databases used & Number of articles & Authors' conclusion \\
\hline 2013 & $\begin{array}{l}\text { Lapkin S, } \\
\text { Levett-Jones T, } \\
\text { and Gilligan } \mathrm{C}^{13}\end{array}$ & $\begin{array}{l}\text { A systematic } \\
\text { review of the } \\
\text { effectiveness of } \\
\text { interprofessional } \\
\text { education in } \\
\text { health } \\
\text { professional } \\
\text { programs }\end{array}$ & $\begin{array}{l}\text { Identify the best } \\
\text { available evidence } \\
\text { for the effectiveness } \\
\text { of university-based } \\
\text { interprofessional } \\
\text { education for health } \\
\text { students. }\end{array}$ & $\begin{array}{l}\text { 1. AMED } \\
\text { 2. CINAHL } \\
\text { 3. Cochrane Central } \\
\text { Register of Controlled } \\
\text { Trials (CENTRAL) } \\
\text { 4. Dissertation and } \\
\text { Theses } \\
\text { 5. EMBASE } \\
\text { 6. ERIC } \\
\text { 7. Journals@Ovid } \\
\text { 8. MEDLINE } \\
\text { 9. ProQuest } \\
\text { 10. PsycINFO } \\
\text { (2000-2011) } \\
\text { Also, hand searched to } \\
\text { find any additional } \\
\text { literature and } \\
\text { unpublished studies: } \\
\text { 1. Journal of } \\
\text { Interprofessional Care } \\
\text { 2. Conference } \\
\text { Proceedings } \\
\text { 3. Directory of open } \\
\text { access journals } \\
\text { 4. Mednar }\end{array}$ & $\begin{array}{l}\text { The search strategy } \\
\text { identified } 4217 \text { articles, of } \\
\text { which } 75 \text { articles were } \\
\text { deemed potentially } \\
\text { relevant based on the } \\
\text { assessment of title and } \\
\text { abstracts. Nine published } \\
\text { studies consisting of three } \\
\text { randomized controlled } \\
\text { trials, five controlled before } \\
\text { and after studies and one } \\
\text { controlled longitudinal } \\
\text { study were included in the } \\
\text { review. }\end{array}$ & $\begin{array}{l}\text { Student's attitudes and } \\
\text { perceptions towards } \\
\text { interprofessional } \\
\text { collaboration and } \\
\text { clinical decision } \\
\text { making can be } \\
\text { potentially enhanced } \\
\text { through } \\
\text { interprofessional } \\
\text { education. However, } \\
\text { the evidence for using } \\
\text { interprofessional } \\
\text { education to teach } \\
\text { communication skills } \\
\text { and clinical skills is } \\
\text { inconclusive and } \\
\text { requires further } \\
\text { investigation. } \\
\text { Little evidence exists in } \\
\text { regards to whether the } \\
\text { gains attributed to IPE } \\
\text { can be sustained over } \\
\text { time. }\end{array}$ \\
\hline
\end{tabular}




\begin{tabular}{|c|c|c|c|c|c|c|}
\hline Date & Authors & Title & Objectives & Databases used & Number of articles & Authors' conclusion \\
\hline 2013 & $\begin{array}{l}\text { Reeves S, } \\
\text { Perrier L, } \\
\text { Goldman J, } \\
\text { Freeth D, and } \\
\text { Zwarenstein } \\
\mathrm{M}^{14}\end{array}$ & $\begin{array}{l}\text { Interprofessional } \\
\text { education: effects } \\
\text { on professional } \\
\text { practice and } \\
\text { healthcare } \\
\text { outcomes } \\
\text { (update) } \\
\text { (Review) }\end{array}$ & $\begin{array}{l}\text { To assess the } \\
\text { effectiveness of IPE } \\
\text { interventions as } \\
\text { compared to } \\
\text { separate, } \\
\text { profession-specific } \\
\text { education } \\
\text { interventions. } \\
\text { To assess the } \\
\text { effectiveness of IPE } \\
\text { interventions as } \\
\text { compared to no } \\
\text { education } \\
\text { intervention. }\end{array}$ & $\begin{array}{l}\text { Cochrane register, } \\
\text { MEDLINE and } \\
\text { CINAHL (2006 - 2011). } \\
\text { Hand searched the } \\
\text { Journal of } \\
\text { Interprofessional Care } \\
\text { (2006 - 2011), reference } \\
\text { lists of all included } \\
\text { studies, the proceedings } \\
\text { of leading IPE } \\
\text { conferences, and } \\
\text { websites of IPE } \\
\text { organizations. }\end{array}$ & $\begin{array}{l}\text { The search strategy } \\
\text { identified } 2733 \text { abstracts. } \\
28 \text { studies were selected } \\
\text { and } 9 \text { were included: } 8 \\
\text { randomized controlled } \\
\text { trials (RCTs), } 5 \text { controlled } \\
\text { before and after (CBA) } \\
\text { studies and } 2 \text { interrupted } \\
\text { time series (ITS) studies. }\end{array}$ & $\begin{array}{l}\text { This updated review } \\
\text { reports on } 15 \text { studies } \\
\text { that met the inclusion } \\
\text { criteria (nine studies } \\
\text { from this update and } \\
\text { six studies from the } \\
2008 \text { update). } \\
\text { Although these studies } \\
\text { reported some positive } \\
\text { outcomes, due to the } \\
\text { small number of } \\
\text { studies and the } \\
\text { heterogeneity of } \\
\text { interventions and } \\
\text { outcome measures, it } \\
\text { is not possible to draw } \\
\text { generalizable } \\
\text { inferences about the } \\
\text { key elements of IPE } \\
\text { and their effectiveness. }\end{array}$ \\
\hline
\end{tabular}


In the above best evidence systematic review of IPE published in 2007, most of the studies evaluated IPE that was delivered to healthcare students during their undergraduate studies. The majority of participants were from medicine, nursing and physiotherapy, with pharmacy students being less prevalent. ${ }^{3}$ This finding was echoed in another review which found that medical students were included in all the studies with high representation by nursing students, and less by students from other health care fields, including pharmacy. ${ }^{4}$ The pharmacy profession was represented in the primary literature reviewed but its perspective and inclusion was not explicit. Hence there is a need to conduct a systematic review to investigate literature that specifically explores the pharmacy perspective on IPE. It would be useful to investigate the interprofessional learning within pharmacy courses, as providing this information can potentially lead to the development of new and innovative teaching strategies which will potentially benefit health professionals. It is interesting to note that after searching the Cochrane Collaboration's database, JBI Database of Systematic Reviews and Implementation Reports and general literature, the authors believe that no systematic review with a uni-professional healthcare perspective has been undertaken previously; therefore, this review will be unique in that it will be the first to investigate a single healthcare profession's perspective about IPE and collaborative practice.

This is the first systematic review investigating pharmacy perspectives of IPE worldwide. It is anticipated that this review will consolidate and synthesize existing findings regarding pharmacy perspectives on IPE and provide a better understanding of what shapes this perspective. It will also provide us with the platform needed to develop and implement IPE activities that are meaningful, comprehensive and unique. The outcomes of this research will provide a set of recommendations to be used by pharmacy and other healthcare educators to plan and implement innovative IPE activities that are relevant and meaningful to students.

\section{Keywords}

interprofessional education; collaborative practice; pharmacy; perspective; pharmacy students pharmacy academics; practicing pharmacists; systematic review

\section{Inclusion criteria}

\section{Types of participants}

The quantitative and qualitative components of this comprehensive systematic review will consider studies that include pharmacy students (undergraduate and postgraduate), practicing pharmacists (community, hospital and primary healthcare) or pharmacy academics (teaching in academic institutions) as participants.

\section{Types of Intervention(s)/phenomena of interest}

The quantitative component of the review will consider studies that investigate interprofessional education and collaborative practice. More specifically, studies that investigate the perspective of pharmacy students, pharmacy academics and practicing pharmacists towards interprofessional education and collaborative practice will be considered.

The qualitative component of this review will consider studies that investigate the phenomena of interest of the perspectives, attitudes, views and experiences of pharmacy students, pharmacy academics and practicing pharmacists toward interprofessional education and collaborative practice. 
Any quantitative or qualitative methods of capturing any of the following will be considered:

- Perspectives

- Experiences

- Attitudes

- Views

of pharmacy students, pharmacy academics and practicing pharmacists towards IPE and collaborative practice.

\section{Types of outcomes}

This review will consider studies that include the following outcomes:

Quantitative outcomes will include participant perspectives including experiences, attitudes or views on IPE as captured by surveys, questionnaires or any other instruments capturing quantitative data.

\section{Context}

The context will be university academic settings and pharmacy practice settings, i.e. community, hospital and primary healthcare worldwide.

\section{Types of studies}

The quantitative component of the review will consider both experimental and epidemiological study designs including prospective and retrospective cohort studies, case control studies and analytical cross sectional studies for inclusion.

The qualitative component of the review will consider studies that focus on qualitative data including, but not limited to, designs such as phenomenology, grounded theory, ethnography, action research and feminist research.

\section{Search strategy}

The search strategy aims to find both types of published studies. A three-step search strategy will be utilized in this review as follows:

1. An initial limited search of MEDLINE and CINAHL will be undertaken followed by an analysis of the text words contained in the title and abstract, and of the index terms used to describe articles.

2. A second search using all identified keywords and index terms will then be undertaken across all included databases.

3. Thirdly, all the reference lists of all identified articles will be searched for any additional relevant studies.

Only studies published in English will be considered for inclusion in this review. Studies published from 1999 will be considered for inclusion in this review. The reason for focusing only on this period is to capture the most recent trends in IPE. 
The databases to be searched include:

- MEDLINE

- EBSCO host

- EMBASE

- CINAHL

- Web of Science

- ScienceDirect

- International Pharmaceutical Abstracts (IPA).

The following will be hand searched to find additional articles:

- Journal of Interprofessional Care (1999-2014), relevant conferences and websites such as:

- All Together Better Health Website

- CAIPE - Centre for the Advancement of Interprofessional Education

- $\mathrm{AHIC}$ - The American Interprofessional Health Collaborative

- $\quad$ AIPPEN - The Australasian Interprofessional Practice and Education Network

- $\quad \mathrm{CIHC}$ - The Canadian Interprofessional Health Collaborative

- $\quad$ EIPEN - The European Interprofessional Practice and Education Network

- JAIPE - The Japan Association for Interprofessional Education

- JIPWEN - The Japan Interprofessional Working and Education Network

- NIPNET - The Nordic Interprofessional Network

The following keywords will be used:

Interprofession* or Inter-profession*, Multidisciplin* or Multi-disciplin*, Perspectives, Attitudes, Experiences; Views; Pharmac*

Studies not involving pharmacy will be excluded to focus on the objectives of the research.

\section{Assessment of methodological quality}

Quantitative studies selected for retrieval will be assessed by two independent reviewers for methodological validity prior to inclusion in the review using standardized critical appraisal instruments from the Joanna Briggs Institute Meta-Analysis of Statistics Assessment and Review Instrument (JBI-MAStARI) (Appendix I). Any disagreements that arise between the reviewers will be resolved through discussion, or with a third reviewer. All reviewers have undertaken the JBI comprehensive systematic review training program.

Qualitative studies selected for retrieval will be assessed by two independent reviewers for methodological validity prior to inclusion in the review using standardized critical appraisal instruments from the Joanna Briggs Institute Qualitative Assessment and Review Instrument (JBI-QARI) (Appendix I). Any disagreements that arise between the reviewers will be resolved through discussion, or with a third reviewer. 


\section{Data extraction}

Data extraction will be conducted independently by two reviewers. Where possible, authors will be contacted for missing or incomplete data.

Quantitative data will be extracted from articles included in the review using the standardized data extraction tool from JBI-MAStARI (Appendix II). The data extracted will include specific details about the interventions, populations, study methods and outcomes of significance to the review question and specific objectives.

Qualitative data will be extracted from articles included in the review using the standardized data extraction tool from JBI-QARI (Appendix II). The data extracted will include specific details about the interventions, populations, study methods and outcomes of significance to the review question and specific objectives.

\section{Data synthesis}

For quantitative data and due to the nature of the review objectives and the data to be extracted, it will not be possible to conduct statistical pooling on the data; rather narrative synthesis will be conducted and the findings will be presented in narrative form with tables, figures and text to aid in data presentation where appropriate.

Qualitative research findings will, where possible, be pooled using JBI-QARI. This will involve the aggregation or synthesis of findings to generate a set of statements that represent that aggregation, JBI Database of Systematic Reviews and Implementation Reports through assembling the findings (Level 1 findings) rated according to their quality, and categorizing these findings on the basis of similarity in meaning (Level 2 findings). These categories will be subjected to a meta-synthesis to produce a single comprehensive set of synthesized findings (Level 3 findings) that can be used as a basis for evidence-based practice. Where textual pooling is not possible, the findings will be presented in narrative form.

\section{Conflicts of interest}

There is no potential conflict of interest anticipated for this systematic review.

\section{Acknowledgements}

This protocol has been peer reviewed by Dr Kay Cooper, Deputy Director of the Scottish Centre for Evidence-based Multi-professional Practice: an Affiliate Center of the Joanna Briggs Institute. 


\section{References}

1. CAIPE 2002, Interprofessional education - a definition, 2002 [Homepage of Centre for the Advancement of Interprofessional Education (CAIPE)], [Internet]. [Cited on 01/06/2015]. Available from: http://caipe.org.uk/about-us/defining-ipe/ [05/11, 2015].

2. Horsburgh m, Lamdin R, Williamson E. Multiprofessional Learning: The Attitudes of Medical, Nursing and Pharmacy Students to Shared Learning. Med Educ 2001; 35(9): 876-883

3. Hammick M, Freeth D, Koppel L, Reeves S, Barr H. A best evidence systematic review of interprofessional education: BEME Guide no. 9. Med Teach 2007; 29(8): 735-751.

4. Remington TL, Foulk MA, Williams BC. Evaluation of evidence for interprofessional education. AM J Pharm Educ 2006; 70(3): 66-66.

5. Reeves S, Zwarenstein M, Goldman J, Barr H, Freeth D, Hammick M, Koppel I. Interprofessional education: effects on professional practice and health care outcomes. Cochrane Database Syst Rev (2008) (1):CD002213.

6. World Health Organization. Framework for action on interprofessional education and collaborative practice, Health Professions Network Nursing and Midwifery Office, Geneva: Department of Human Resources for Health (2010).

7. Buring SM, Bhushan A, Brazeau G, Conway S, Hansen L, Westberg S.. Keys to successful implementation of interprofessional education: learning location, faculty development, and curricular themes. AM J Pharm Educ 2009; 73(4): Article 60.

8. Hepler C, Strand L. Opportunities and responsibilities in pharmaceutical care. Am J Hosp Pharm . 1990; 47: 533-543.

9. Zwarenstein M, Atkins J, Barr H, Hammick M, Koppel I, \& Reeves S. A systematic review of interprofessional education. J Interprof Care 1999; 13(4): 417-424.

10. Zwarenstein M, Reeves S, Barr H, Hammick M, Koppel I, Atkins J. Interprofessional education: effects on professional practice and health care outcomes. Cochrane Database Syst Rev (2001) (1):CD002213.

11. Cooper H, Carlisle C, Gibbs T, Watkins C. Developing an evidence base for interdisciplinary learning: a systematic review. J Adv Nurs 2001; 35 (2): 228 - 237

12. Clifton M, Dale C, Bradshaw C. Impact and effectiveness of inter-professional education in primary care: an RCN literature review. London: The Royal College of Nurisng Primary Care Educators Forum (2007).

13. Lapkin S, Levett-Jones T, Gilligan C. A systematic review of the effectiveness of interprofessional education in health professional programs. Nurse Educ Today 2013; 33(2): 90-102.

14. Reeves S, Perrier L, Goldman J, Freeth D, Zwarenstein M. Interprofessional education: Effects on professional practice and health care outcomes (update). Cochrane Database Syst Rev, 3 , CD002213 (2013). 


\section{Appendix I: Appraisal instruments \\ QARI appraisal instrument}

\section{JBI QARI Critical Appraisal Checklist for Interpretive \& Critical Research}

Reviewer . Author Record Number

. Is there congruity between the stated philosophical perspective and the research methodology?

2 . Is there congruity between the research methodology and the research question or objectives?

3 . Is there congruity between the research methodology and the methods used to collect data?

4. Is there congruity between the research methodology and the representation and analysis of data?

5 . Is there congruity between the research methodology and the interpretation of results?

6. Is there a statement locating the researcher culturally or theoretically?

7. Is the influence of the researcher on the research, and vice- versa, addressed?

8. Are participants, and their voices, adequately represented?

Yes No Unclear Not Applicable

Is the research ethical according to current criteria or, for recent studies, and is there evidence of ethical approval by an appropriate body?

10. Do the conclusions drawn in the research report flow from the analysis, or interpretation, of the data?

Overall appraisal:

Include

Exclude

Seek further info.

Comments (Including reason for exclusion) 


\section{MAStARI appraisal instrument}

\section{JBI Critical Appraisal Checklist for Randomised Control / Pseudo-randomised Trial}

\begin{tabular}{|c|c|c|c|c|}
\hline \multicolumn{5}{|c|}{ Reviewer . $\ldots \ldots$ Date } \\
\hline \multicolumn{5}{|c|}{ 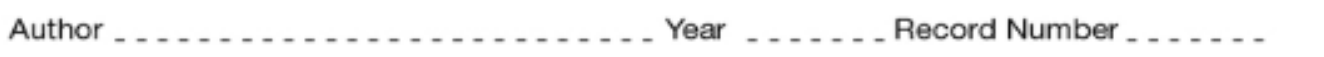 } \\
\hline & Yes & No & Unclear & Not Applicable \\
\hline $\begin{array}{l}\text { 1. Was the assignment to treatment } \\
\text { groups truly random? }\end{array}$ & $\square$ & $\square$ & $\square$ & $\square$ \\
\hline $\begin{array}{l}\text { 2. Were participants blinded to } \\
\text { treatment allocation? }\end{array}$ & $\square$ & $\square$ & $\square$ & $\square$ \\
\hline $\begin{array}{l}\text { 3. Was allocation to treatment groups } \\
\text { concealed from the allocator? }\end{array}$ & $\square$ & $\square$ & $\square$ & $\square$ \\
\hline $\begin{array}{l}\text { 4. Were the outcomes of people who } \\
\text { withdrew described and included in } \\
\text { the analysis? }\end{array}$ & $\square$ & $\square$ & $\square$ & $\square$ \\
\hline $\begin{array}{l}\text { 5. Were those assessing outcomes } \\
\text { blind to the treatment allocation? }\end{array}$ & $\square$ & $\square$ & $\square$ & $\square$ \\
\hline $\begin{array}{l}\text { 6. Were the control and treatment } \\
\text { groups comparable at entry? }\end{array}$ & $\square$ & $\square$ & $\square$ & $\square$ \\
\hline $\begin{array}{l}\text { 7. Were groups treated identically } \\
\text { other than for the named } \\
\text { interventions }\end{array}$ & $\square$ & $\square$ & $\square$ & $\square$ \\
\hline $\begin{array}{l}\text { 8. Were outcomes measured in the } \\
\text { same way for all groups? }\end{array}$ & $\square$ & $\square$ & $\square$ & $\square$ \\
\hline $\begin{array}{l}\text { 9. Were outcomes measured in a } \\
\text { reliable way? }\end{array}$ & $\square$ & $\square$ & $\square$ & $\square$ \\
\hline \multirow{2}{*}{$\begin{array}{l}\text { 10. Was appropriate statistical analysis } \\
\text { used? }\end{array}$} & $\square$ & $\square$ & $\square$ & $\square$ \\
\hline & $\square$ & $\square$ & $\square$ & $\square$ \\
\hline Overall appraisal: & Exclude & $\square$ & \multicolumn{2}{|c|}{ Seek further info. $\square$} \\
\hline
\end{tabular}




\section{JBI Critical Appraisal Checklist for Descriptive / Case Series}

Reviewer
Record Number

1. Was study based on a random or pseudorandom sample?

2. Were the criteria for inclusion in the sample clearly defined?

3. Were confounding factors identified and strategies to deal with them stated?

4. Were outcomes assessed using objective criteria?

5. If comparisons are being made, was there sufficient descriptions of the groups?

6. Was follow up carried out over a sufficient time period?

7. Were the outcomes of people who withdrew described and included in the analysis?

8. Were outcomes measured in a reliable way?

9. Was appropriate statistical analysis used?

Overall appraisal: $\quad$ Include $\square \quad$ Exclude $\square \quad$ Seek further info 


\section{JBI Critical Appraisal Checklist for Comparable Cohort/ Case Control}

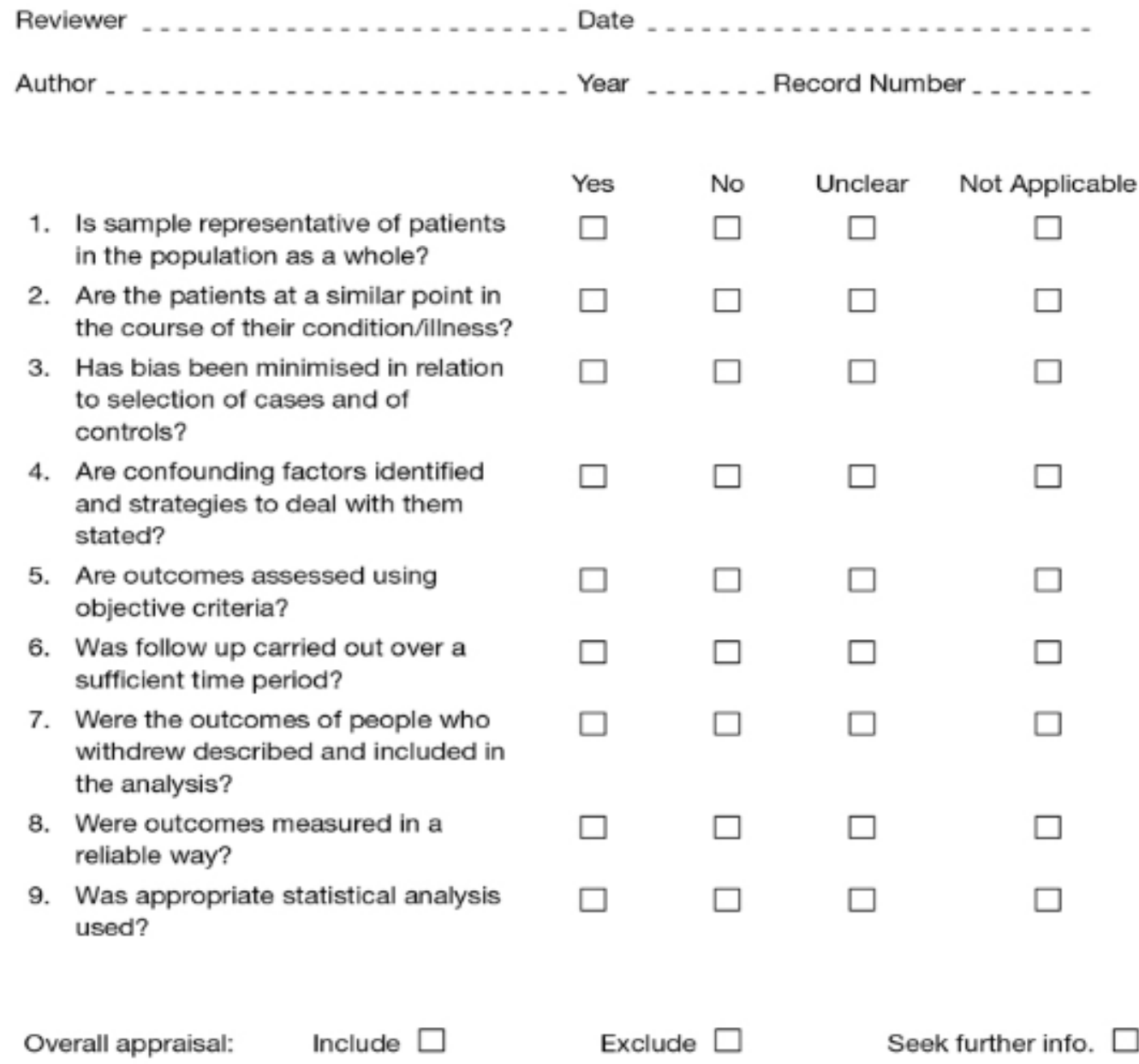

Comments (Including reason for exclusion) 


\section{Appendix II: Data extraction instruments}

QARI data extraction instrument

\section{JBI QARI Data Extraction Form for Interpretive \& Critical Research}

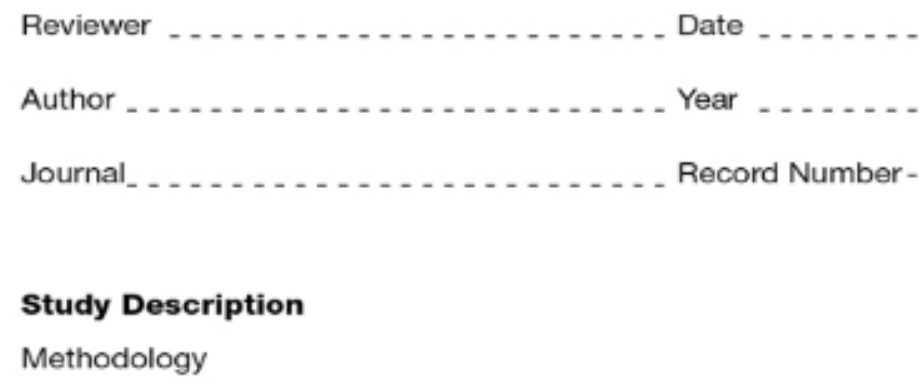




\begin{tabular}{|l|l|l|l|l|}
\hline \multirow{2}{*}{ Findings } & \multirow{2}{*}{$\begin{array}{c}\text { IIIustration from } \\
\text { Publication } \\
\text { (page number) }\end{array}$} & Unequivocal & Credible & Unsupported \\
\hline & & & & \\
\hline & & & & \\
\hline & & & & \\
\hline & & & & \\
\hline & & & & \\
\hline & & & & \\
\hline & & & & \\
\hline & & & & \\
\hline & & & & \\
\hline & & & & \\
\hline & & & & \\
\hline & & & & \\
\hline
\end{tabular}

Extraction of findings complete Yes $\square$ No $\square$ 


\section{JBI Data Extraction Form for Experimental / Observational Studies}

Reviewer

Date

Author Year

Journal

Record Number

Study Method

$\mathrm{RCT}$

$\square$

Quasi-RCT

Longitudinal

Retrospective

Observational

Other

\section{Participants}

Setting

Population

Sample size

Group A

Group B

Interventions

Intervention A

Intervention B

Authors Conclusions:

Reviewers Conclusions: 


\section{Study results}

Dichotomous data

\begin{tabular}{|l|l|l|}
\hline Outcome & $\begin{array}{c}\text { Intervention ( ) } \\
\text { number/total number }\end{array}$ & $\begin{array}{c}\text { Intervention ( ) } \\
\text { number/total number }\end{array}$ \\
\hline & & \\
\hline & & \\
\hline & & \\
\hline & & \\
\hline
\end{tabular}

Continuous data

\begin{tabular}{|l|l|l|}
\hline Outcome & $\begin{array}{c}\text { Intervention ( } \\
\text { number/total number }\end{array}$ & $\begin{array}{c}\text { Intervention ( } \\
\text { number/total number }\end{array}$ \\
\hline & & \\
\hline & & \\
\hline & & \\
\hline & & \\
\hline
\end{tabular}

